\title{
HUBUNGAN KEKUATAN OTOT LENGAN DAN KOOORDINASI MATA-TANGAN DENGAN KETERAMPILAN SERVIS ATAS BOLAVOLI SISWA SMP 74 JAKARTA TIMUR
}

\author{
Muhammad Aspar ${ }^{1}$, Galang Pakarti Mahardika ${ }^{2}$, Muhammad Ishaq Gery ${ }^{3}$ \\ ${ }^{1}$ Pendidikan Olahraga, Fakultas Ilmu Pendidikan, Universitas Muhammadiyah Jakarta
}

masparrivai@gmail.com

\begin{abstract}
ABSTRAK
Penelitian ini bertujuan untuk mengetahui; (1) hubungan antara kekuatan otot lengan dengan keterampilan servis atas bolavoli, (2) hubungan antara koordinasi mata-tangan dengan keterampilan servis atas bolavoli, dan (3) hubungan antara kekuatan otot lengan dan koordinasi mata-tangan secara bersama-sama dengan keterampilan servis atas bolavoli. Penelitian ini dilakukan di SMP Negeri 74 Jakarta Timur pada ekstrakulikuler olahraga Bolavoli. Metode penelitian yang digunakan adalah kuantitatif deskriptif dengan teknik korelasional. Populasi dalam penelitian ini adalah siswa yang mengikuti ekstrakulikuler Bolavoli di SMP Negeri 74 Jakarta Timur DKI Jakarta sebanyak 45 orang. Analisis data menggunakan statistik korelasional dan regresi dengan taraf signifikan $\alpha=0,05$. Kesimpulan penelitian ini adalah terdapat hubungan yang positif dan signifikan antara kekuatan otot lengan dan koordinasi mata-tangan dengan keterampilan servis atas bolavoli SMP Negeri 74 Jakarta Timur.
\end{abstract}

Kata Kunci: Bolavoli, Servis Atas

\begin{abstract}
This study aims to see; (1) the relationship between arm muscle strength and volleyball skills, (2) the relationship between eye-hand coordination and volleyball skills, and (3) the relationship between arm muscle strength and eye-hand coordination together with service skills over volleyball. This research was conducted at SMP Negeri 74 East Jakarta on the extracurricular sport of volleyball. The research method used is descriptive quantitative with correlational techniques. The population in this study were 45 students who took part in the extracurricular activity of Bolavoli at SMP Negeri 74 East Jakarta, DKI Jakarta. Data analysis used correlational statistics and regression with a significant level of $\alpha=0.05$. This conclusion is that there is a positive and significant relationship between arm muscle strength and eye-hand coordination with volleyball skills in SMP Negeri 74 East Jakarta.
\end{abstract}

Keywords: Volleyball, Top Service

Dipublikasikan Oleh :

UPT Publikasi dan Pengelolaan Jurnal

Universitas Islam Kalimantan Muhammad Arsyad Al-Banjari Banjarmasin 


\section{PENDAHULUAN}

Permainan bolavoli merupakan permainan yang kompleks yang tidak mudah dilakukan oleh setiap orang. Sebab, dalam permainan bolavoli dibutuhkan koordinasi gerak yang benar-benar bisa diandalkan untuk melakukan semua gerakan yang ada dalam permainan bolavoli. Walaupun begitu, permainan bolavoli sangat cepat berkembang dan merupakan salah satu olahraga yang sangat populer di Indonesia saat ini (Ahmadi, 2008). Munasifah (Munasifah, 2009) menyatakan bahwa, "bolavoli adalah permainan yang dilakukan dua regu, yang masing- masing terdiri dari enam orang. Bola dimainkan diudara dengan melewati net, setiap regu hanya bisa memain bola tiga kali pukulan". Lebih lanjut lagi bolavoli merupakan olahraga yang unik karena olahraga ini merupakan kesalahan yang memiliki tujuan mendapatkan bola untuk dipukul kedaerah lapangan lawan atau memaksa lawan melakukan kesalahan dalam menangani bola. Lebih lanjut lagi dikemukakan Bergeles Nikos dkk (Nikos, Karolina, \& Grigoris, 2010), bahwa Volleyball is an interactive game and can be divided into the two main phases of attack and defense, each having three or four sequential skill events that are expected to occur sequentially in a hierarchical order. Bolavoli adalah olahraga permainan yang dimainkan oleh dua grup berlawanan. Masing-masing grup memiliki enam orang pemain ssehingga permainan bolavoli sangat menarik untuk dimainkan.

Barbara L Viera dan Bonnie Jill Ferguson (Viera \& Ferguson, 2010) menyatakan kelebihan-kelebihan lain dari permainan bolavoli antara lain (1) It is adaptable to various conditions that may present themselves, (2) It can be played with any number on a side from two, which is extremely popular in the beach game, to six. which is the number used for interscholastic, intercollegiate, junior, and club play, (3) It can be played and enjoyed by all ages and ability levels, (4) It can be played on many surfaces-grass, wood, sand, and various artificial surfaces, (5) It is an excellent co-ed activity, (6) It is an exciting spectator sport, (7) It can be played indoors or outdoors, (8) It is an extremely popular recreational activity with numerous leagues in business,community, and school intramural programs, (9) It requires few basic rules and skills, and (10) It has limited equipment needs. Dalam permainan bolavoli ada beberapa bentuk teknik dasar yang harus dikuasai, teknik dalam permainan bolavoli terdiri atas servis, passing, block, dan smash (Ahmadi, 2008).

Servis adalah pukulan bola yang dilakukan dari belakang garis akhir lapangan permainan melampaui net ke daerah lawan. Pukulan servis dilakukan pada permulaan dan setelah terjadinya setiap kesalahan. Karena pukulan servis berperan besar untuk memperoleh poin, maka pukulan servis harus meyakinkan, terarah, keras, dan menyulitkan lawan. Ada beberapa jenis servis dalam permainan bolavoli, di antaranya servis lengan bawah ( under servis ), servis tangan samping ( side hard service), servis atas kepala ( over head service), servis mengambang ( floating service), servis topspin dan servis loncat ( jump servis). Kita akan membahas beberapa di antara jenis-jenis servis tersebut. Yang pasti, prioritas dalam servis adalah menyeberangkan bola melewati net setiap kali servis (Ahmadi, 2008).

Faktor-faktor kelengkapan yang harus dimiliki seseorang bila ingin mencapai prestasi yang optimal yaitu : 1) pengembangan fisik, 2) pengembangan teknik, 3) pengembangan mental, dan 4) kematangan juara. Kemudian faktor-faktor penentu pencapaian prestasi olahraga meliputi aspek biologis terdiri dari : 1) potensi atau kemampuan dasar tubuh yang meliputi kekuatan, kecepatan, kelincahan tenaga, daya tahan otot, daya kerja jantung dan paru-paru, kelentukan, keseimbangan, ketepatan dan kesehatan olahraga, 2) fungsi organ tubuh yang meliputi daya kerja jantung, daya kerja pernafasan, daya kerja panca indera, 3) struktur dan postur tubuh yang meliputi ukuran tinggi dan panjang tubuh, ukuran besar, lebar dan bentuk tubuh, dan 4) gizi yang meliputi jumlah makanan yang cukup, nilai makanan yang memenuhi kebutuhan, variasi makanan.

Pembinaan yang dilakukan dalam pelaksanaan latihan, terkadang kurang seimbang dalam pemberian materi antara keterampilan teknik dasar bermain ataupun latihan kondisi fisik. Diumpamakan jika kedua hal tersebut dibandingkan, perbandingan latihan yang tidak seimbang akan berpengaruh pada saat tampil dalam pertandingan maupun dalam hasil akhir program, sehingga harapan untuk meraih kemenangan kemungkinan kecil. Untuk itulah dalam upaya peningkatan prestasi olahraga perlu diusahakan pembinaan yang terarah dan berkelanjutan lewat pemanduan bakat, pembibitan, pendidikan serta pelatihan olahraga yang didasarkan pada ilmu pengetahuan secara efektif dan efisien sebagai sarana, mencapai prestasi optimal.

Seperti halnya penulis menggambarkan keadaan siswa SMP Negeri 74 Jakarta Timur yang mengikuti ekstrakulikuler olahraga Bolavoli rata-rata memiliki postur tubuh yang lumayan tinggi, sehingga memunculkan ide bagi penulis sebagai bahan penelitian. Sejauh mana siswa melakukan servis atas bolavoli dengan postur tubuh yang memadai. Perlu juga diupayakan langkah-langkah nyata mulai dari perbaikan metode latihan, peningkatan sarana prasarana, penggunaan peralatan yang baik dan standar, perhatian masalah gizi, tes dan pengukuran dalam olahraga sampai pada perhatian terhadap tim dokter dan psikolog yang diperlukan.

Permainan bolavoli membutuhkan jangkauan atau raihan dimana sangat dibutuhkan oleh atlit dalam permainan. Rostislav Vorálek dkk (Vorálek, Tichý, \& Süss, 2010), menjelaskan bahwa Game performance in volleyball does not exert extreme demands on flexibility, it is very important to develop optimal range of motion in joints and related functions of individual muscles and muscle groups. Dalam olahraga bukan hanya tentang

Dipublikasikan Oleh :

UPT Publikasi dan Pengelolaan Jurnal

Universitas Islam Kalimantan Muhammad Arsyad Al-Banjari Banjarmasin 
somatotype, namun postur badan atlit yang harus disesuaikan dengan kecabangannya. Seperti halnya bolavoli yang mengandalkan panjang dan raihan. Seperti yang dijelaskan Nikos, Karolina, \& Malousaris, (2010) menjelaskan bahwa Along with progress in the field of sport performance enhancement in volleyball, there is information dealing not only with volleyball player's somatotype, his body height or actual or appropriate body weight, but often the total quality of a player's body composition is evaluated in the scientific literature involving sport practice. Kemampuan atlet bolavoli perlu ditingkatkan. Unsur-unsur yang meliputi kondisi fisik, teknik, taktik, kematangan mental, kerjasama dan pengalaman dalam bertanding Sebagai faktor pendukung untuk mempercepat tercapainya tujuan permainan bolavoli antara lain, faktor endogen dan pemain yang terdiri dari : 1) kesehatan fisik dan mental, 2) bentuk tubuh sesuai cabang olahraga yang diikuti, untuk cabang bolavoli diharapkan yang tinggi dan atletis, 3) punya bakat untuk bermain bolavoli yang meliputi kemampuan fisik, teknik, dan taktik, 4) dimiliki sikap mental yang baik seperti sosial, disiplin, tekun, kreatif bertanggung jawab dan berkemauan keras. Permainan bolavoli adalah permainan tempo cepat sehingga waktu untuk bermain sangat terbatas apabila tidak sesuai teknik dasar yang sempurna, akan dimungkinkan kesalahan yang lebih besar Servis merupakan salah satu teknik dalam permainan bolavoli. Pada mulanya servis merupakan pukulan awal untuk memulai suatu permainan, tetapi jika ditinjau dari sudut taktik sudah merupakan suatu serangan awal untuk memperoleh nilai agar suatu regu berhasil meraih kemenangan. Karena, sangat penting teknik servis dalam bolavoli maka perlu syarat tertentu sebagai modal dalam melakukan servis di antaranya memiliki kondisi fisik yang memadai berupa kekuatan dan kecepatan. Sebab, untuk melakukan servis yang baik harus mempunyai keterampilan khusus. Misalnya kecepatan gerak lengan ketika memukul bola, kekuatan otot lengan untuk tenaga, ayunan lengan agar bola mampu melaju cepat dan keras dan koordinasi mata tanga untuk ketepatan dalam mengarahkan bola ke daerah lawan.

Kemampuan untuk menghasilkan kekuatan tergantung pada panjang tuas yang terlibat, dengan kata lain panjang tungkai yang terlibat dalam gerakan tersebut, hal ini terjadi karena tuas tersebut menghasilkan kekuatan yang diterapkan (Gordon, 2009). Kekuatan otot lengan atau strength adalah kemampuan otot untuk membangkitkan tegangan terhadap suatu tahanan. Koordinasi merupakan keterpaduan dari beberapa bagian tubuh dan otot. Servis adalah sentuhan pertama dengan bola. Kekuatan terbentuk dari kontraksi otot saat menahan beban. Kontaksi otot sendiri terdiri dari 3 tipe yang berdasarkan gerakannya, yaitu isometrik, konsentrik, dan eksentrik (Gordon, 2009). Koordinasi sangat diperlukan dalam permainan bolavoli. Komponen biomotor koordinasi diperlukan hampir di semua cabang olahraga pertandingan maupun perlombaan, sebab unsur-unsur dasar teknik gerak dalam cabang olahraga melibatkan sinkronisasi dari beberapa kemampuan (Sukadiyanto \& Muluk, 2011). Koordinasi dapat juga diartikan sebagai kemampaun untuk menyongsong dari bekerjanya suatu otot. Koordinasi merupakan penyesuian yang berpengaruh tarhadap sekelompok otot dan selama melakukan gerakan yang memberikan indikasi terhadap berbagai keterampilan. Seseoranga yang memiliki koordinasi baik maka orang tersebut akan mampu untuk melakukan gerakan berbagi tingkat kesulitan dengan cepat, efisien dan penuh ketepatan.

Permainan bolavoli adalah permainan beregu yang memerlukan koordiansi yang perliu dimiliki dari tiap-tiap individu pemain. Oleh dari itu setiap pemain diperliukan fisik yang kuat, serta tingkat keterampilan yang tinggi. Oleh sebab itu dalam penelitian ini akan dibahas tentang kekuatan otot lengan dan kordinasi matatangan dengan keterampilan servis atas bolavoli. Karena dalam melakukan servis atas bolavoli kekuatan otot lengan dan koordinasi mata tangan diperlukan sekali dalam kecepatan dan ketepatan bola masuk kedaerah lawan.

\section{METODE PENELITIAN}

Metode penelitian yang digunakan adalah kuantitatif deskriptif dengan teknik korelasional. Penelitian survei bersifat non eksperimen, karena pelaku tidak melakukan intervensi terhadap variabel-variabel yang diteliti. Penelitian ini melibatkan 2 macam variabel: 1). Keterampilan servis atas bolavoli sebagai variabel terikat. 2). Kekuatan otot lengan, dan koordinasi mata-tangan sebagai variabel bebas.

Populasi dalam penelitian ini adalah 45 siswa SMP Negeri 74 Jakarta Timur yang mengikuti ekstrakulikuler Bolavoli, teknik pengambilan sampel menggunakan total sampling atau seluruh populasi digunakan sebagai sampel dalam penelitian.

Teknik pengumpulan data menggunakan tes, pada tes kekuatan otot menggunakan tes angkat tubuh 30 detik, tes koordinasi mata-tangan menggunakan Barrow Motor Ability Tes (tes lempar tangkap bola basket ke dinding selama 15 detik) dan pada tes servis atas bolavoli menggunakan lapangan berpoin. Teknik pengujian Hipotesis dalam penelitian ini menggunakan analisis regresi dan korelasi.

Dipublikasikan Oleh :

UPT Publikasi dan Pengelolaan Jurnal

Universitas Islam Kalimantan Muhammad Arsyad Al-Banjari Banjarmasin 


\section{HASIL PENELITIAN DAN PEMBAHASAN}

Deskripsi data dalam penelitian ini meliputi: (1) keterampilan servis atas bolavoli, sebagai variabel dependen, (2) kekuatan otot lengan dan (3) koordinasi mata-tangan, sebagai variabel independen.

Persyaratan lain yang harus dipenuhi dalam melakukan analisis dalam penelitian ini adalah variabelvariabel yang dirumuskan mempunyai hubungan linier secara signifikan, karena itu dilakukan uji signifikansi dan linieritas model regresi linier sederhana sesuai dengan model hubungan antar variabel yang dirumuskan dalam hipotesis.

Pengujian hipotesis dilakukan setelah uji persyaratan analisis menghasilkan skor tiap variabel penelitian yang memmenuhi syarat untuk pengujian statistik. Tujuan hipotesis statistik adalah untuk mencari jawaban apakah hipotesis nol (Ho) yang diajukan ditolak atau sebaliknya pada taraf kepercayaan tertentu. Selanjutnya dalam penelitian ini, yang ingin diketahui adalah hubungan antara kedua variabel bebas dengan satu variabel terikat, baik secara sendiri-sendiri maupun bersama-sama, Kemudian untuk mengetahui hubungan tersebut dilakukan korelasi sederhana dan korelasi ganda.

Hubungan antara Keterampilan Servis Atas Bolavoli (Y) dengan Kekuatan Otot Lengan (X1)

Penelitian ini mengajukan hipotesis pertama yang menyatakan bahwa "terdapat hubungan antara kekuatan otot lengan dengan Keterampilan servis atas bolavoli".

Selanjutnya dilakukan pengujian koefisien korelasi dengan Pearson Product Moment terhadap hubungan antara kekuatan otot lengan (X1) dengan Keterampilan servis atas bolavoli (Y). Dari hasil perhitungan diperoleh koefisien korelasi ry1 $=0,422$. kemudian terhadap nilai korelasi tersebut dilakukan pengujian signifikansi dengan menggunakan uji-t (statistik t-student) dan hasil perhitungan dapat dilihat pada tabel 1 dibawah ini.

Tabel 1. Uji Signifikansi Korelasi $X_{1}$ dengan $Y$

\begin{tabular}{|c|c|c|c|}
\hline Koefisien korelasi & $\mathbf{t}_{\text {hitung }}$ & $\mathbf{t}_{\text {tabel }(\boldsymbol{\alpha}=\mathbf{0 , 0 5})}$ & $\mathbf{t}_{\text {tabel }(\boldsymbol{\alpha}=\mathbf{0 , 0 1})}$ \\
\hline 0,422 & $3,223 * *$ & 2,011 & 2,682 \\
\hline
\end{tabular}

Keterangan : $* * *$ sangat signifikan

Dilihat dari tabel 1 bahwa $t_{\text {hitung }}=3,223$ lebih besar dari pada $t_{\text {tabel }}=2,011$ pada derajat kebebasan 49 baik taraf nyata $\alpha=0,05$ maupun pada taraf nyata $\alpha=0,01\left(\mathrm{t}_{\text {tabel }}=2,682\right)$. Hal ini berarti bahwa hubungan antara kekuatan otot lengan $\left(\mathrm{X}_{1}\right)$ dengan Keterampilan servis atas bolavoli $(\mathrm{Y})$ adalah sangat signifikan. Temuan ini menyimpulkan bahwa terdapat hubungan positif kekuatan otot lengan dengan Keterampilan servis atas bolavoli.

Dari koefisien korelasi diperoleh koefisien determinasi hubungan antara kekuatan otot lengan (X1) dengan Keterampilan servis atas bolavoli (Y) sebesar $(0,422) 2=0,178$. Hal ini berarti $17,8 \%$ variasi kecenderungan Keterampilan servis atas bolavoli (Y) dapat dijelaskan oleh kekuatan otot lengan (X1). Dengan kata lain, kekuatan otot lengan memberi kotribusi relatif sebesar 17,8\% terhadap Keterampilan servis atas bolavoli

\section{Hubungan antara Keterampilan servis atas bolavoli (Y) dengan Koordinasi Mata-Tangan (X2)}

Penelitian ini mengajukan hipotesis pertama yang menyatakan bahwa "terdapat hubungan antara koordinasi mata-tangan dengan keterampilan servis atas bolavoli”. Selanjutnya dilakukan pengujian koefisien korelasi dengan Pearson Product Moment terhadap hubungan antara Koordinasi Mata-Tangan (X2) dengan keterampilan servis atas bolavoli (Y). Dari hasil perhitungan diperoleh koefisien korelasi ry2 $=0,475$. kemudian terhadap nilai korelasi tersebut dilakukan pengujian signifikansi dengan menggunakan uji-t (statistik t-student) dan hasil perhitungan dapat dilihat pada tabel 2 dibawah ini.

Tabel 2 Uji Signifikansi Korelasi $X_{2}$ dengan $Y$

\begin{tabular}{|c|c|c|c|}
\hline $\begin{array}{c}\text { Koefisien } \\
\text { korelasi }\end{array}$ & $\mathbf{t}_{\text {hitung }}$ & $\mathbf{t}_{\text {tabel }(\boldsymbol{\alpha}=\mathbf{0 , 0 5})}$ & $\mathbf{t}_{\text {tabel }(\boldsymbol{\alpha}=\mathbf{0 , 0 1})}$ \\
\hline 0,475 & $3,741 * *$ & 2,011 & 2,682 \\
\hline
\end{tabular}

Keterangan : $* * *$ sangat signifikan

Dilihat dari tabel 2 bahwa thitung = 3,741 lebih besar dari pada ttabel $=2,011$ pada derajat kebebasan 48 baik taraf nyata $\square=0,05$ maupun pada taraf nyata $\square=0,01$ (ttabel $=2,682$ ). Hal ini berarti bahwa hubungan antara Koordinasi Mata-Tangan (X2) dengan keterampilan servis atas bolavoli (Y) adalah sangat signifikan.

Dipublikasikan Oleh :

UPT Publikasi dan Pengelolaan Jurnal

Universitas Islam Kalimantan Muhammad Arsyad Al-Banjari Banjarmasin 
Dari koefisien korelasi diperoleh koefisien determinasi hubungan antara Koordinasi Mata-Tangan (X2) dengan keterampilan servis atas bolavoli (Y) sebesar $(0,475) 2=0,226$. Hal ini berarti $22,6 \%$ variasi kecenderungan keterampilan servis atas bolavoli (Y) dapat dijelaskan oleh Koordinasi Mata-Tangan (X2). Dengan kata lain, Koordinasi Mata-Tangan memberi kotribusi relatif sebesar 22,6\% terhadap keterampilan servis atas bolavoli.

\section{Hubungan antara Keterampilan Servis Atas Bolavoli (Y) dengan Kekuatan Otot Lengan (X1) dan Koordinasi Mata-Tangan (X2).}

Penelitian ini mengajukan hipotesis pertama yang menyatakan bahwa "terdapat hubungan antara koordinasi mata-tangan dengan kekuatan otot lengan dan keterampilan servis atas bolavoli”.

Pengujian koefisien korelasi dengan Pearson Product Moment terhadap hubungan antara kekuatan otot lengan(X1) dan koordinasi mata-tangan (X2) dengan keterampilan servis atas bolavoli (Y). Dari hasil perhitungan diperoleh koefisien korelasi ry12 $=0,550$. kemudian terhadap nilai korelasi tersebut dilakukan pengujian signifikansi dengan menggunakan uji-F dan hasil perhitungan dapat dilihat pada tabel 3 dibawah ini.

Tabel 3 Uji Signifikansi Korelasi $X_{1}$ dan $X_{2}$ dengan $Y$

\begin{tabular}{|c|c|c|c|}
\hline $\begin{array}{c}\text { Koefisien } \\
\text { korelasi }\end{array}$ & $\mathbf{F}_{\text {hitung }}$ & $\mathbf{F}_{\text {tabel }(\boldsymbol{\alpha}=\mathbf{0 , 0 5})}$ & $\mathbf{t}_{\text {tabel }(\boldsymbol{\alpha}=\mathbf{0 , 0 1})}$ \\
\hline 0,550 & $10,217 * *$ & 3,195 & 5,087 \\
\hline
\end{tabular}

Keterangan : $* *=$ sangat signifikan

Dilihat dari tabel 3 bahwa $t_{\text {hitung }}(10,217)$ lebih besar dari pada $t_{\text {tabel }}(5,087)$ pada derajat kebebasan 47 pada taraf nyata $\alpha=0,01$. Hal ini berarti bahwa hubungan antara kekuatan otot lengan dan koordinasi matatangan dengan keterampilan servis atas bolavoli adalah sangat signifikan.

\section{PENUTUP}

Pertama, kekuatan otot lengan terdapat hubungan positif dengan keterampilan servis atas bolavoli. Hasil penelitian menunjukkan bahwa kekuatan otot lengan berhubungan positif dengan keterampilan servis atas bolavoli temuan ini menyimpulkan bahwa terdapat hubungan yang positif antara kekuatan otot lengan dengan keterampilan servis atas bolavoli dengan koefisien korelasi sebesar 0,422, dan nilai t hitung adalah sebesar 3,223 yang lebih besar dari $t_{\text {tabel }}=2,682$ pada taraf signifikansi $\alpha=0,01$. Hal ini berarti tinggi rendahnya kekuatan otot lengan berhubungan dengan baik atau buruknya keterampilan servis atas bolavoli SMP Negeri 74 Jakarta Timur.

Kedua, Koordinasi Mata-Tangan terdapat hubungan positif dengan keterampilan servis atas bolavoli. Hasil penelitian menunjukkan bahwa koordinasi mata-tangan berhubungan positif dengan keterampilan servis atas bolavoli temuan ini menyimpulkan bahwa terdapat hubungan yang positif antara koordinasi mata-tangan dengan keterampilan servis atas bolavoli dengan koefisien korelasi sebesar 0,475 , dan nilai t hitung adalah sebesar 3,741 yang lebih besar dari $t_{\text {tabel }}=2,682$ pada taraf signifikansi $\alpha=0,01$. Hal ini berarti baik atau buruknya koordinasi mata-tangan berhubungan dengan baik atau buruknya keterampilan servis atas bolavoli SMP Negeri 74 Jakarta Timur.

Ketiga, kekuatan otot lengan dan koordinasi mata-tangan secara bersama terdapat hubungan positif dengan keterampilan servis atas bolavoli. Hasil penelitian menunjukkan bahwa kekuatan otot lengan dan koordinasi mata-tangan secara bersama-sama berhubungan positif dengan keterampilan servis atas bolavoli, temuan ini menyimpulkan bahwa terdapat hubungan yang positif antara kekuatan otot lengan dan koordinasi mata-tangan secara bersama-sama dengan keterampilan servis atas bolavoli dengan koefisien korelasi sebesar 0,550, dan nilai $F_{\text {hitung }}$ adalah sebesar 10,217 yang lebih besar dari $F_{\text {tabel }}=5,087$ pada taraf signifikansi $\alpha=0,01$. Hal ini berarti tinggi rendahnya kekuatan otot lengan dan baik atau buruknya koordinasi mata-tangan secara bersama berhubungan secara positif dengan baik atau buruknya keterampilan servis atas bolavoli SMP Negeri 74 Jakarta Timur.

\section{REFERENSI}

Ahmadi, N. (2008). Panduan Olahraga Bolavoli. Yogyakarta: Era Pustaka.

Gordon, D. (2009). Coaching Science. Cornwall: Learning Matters.

Munasifah. (2009). Bermain Bola Voli. Semarang: Aneka Ilmu.

Nikos, B., Karolina, B., \& Grigoris, M. (2010). Performance effectiveness in Complex II of Olympic-level male Dipublikasikan Oleh : 
and female volleyball players. The Official Journal of USA Volleyball's Sports Medicine and Performance Commission, 10(1).

Nikos, B., Karolina, B., \& Malousaris, G. (2010). Performance effectiveness in Complex II of Olympic-level male and female volleyball players. International Journal of International Journal of Volleyball Research, 10(1), 20-25. from http://www.fivb.org/en/medical/document/2010_ijvr.pdf\#page=21

Sukadiyanto, \& Muluk, D. (2011). Pengantar Teori dan Metodologi Melatih Fisik. Bandung: Lubuk Agung.

Viera, B. L., \& Ferguson, B. J. (2010). Volley ball Step to Succes Second Edition. Canada: Human Kinetics.

Vorálek, R., Tichý, M., \& Süss, V. (2010). Movement analysis related to functional characteristics of upper extremities in female junior volleyball players. International Journal of Volleyball Research Official Publication of USA Volleyball, 10. 1, 23-27. Retrieved from http://www.fivb.org/en/medical/document/2010_ijvr.pdf\#page=21 